\title{
KONSEP PEMBENTUKAN PERATURAN PERUNDANG-UNDANGAN DI INDONESIA
}

\author{
Ferry Irawan Febriansyah \\ STAI Muhammadiyah Tulungagung \\ e-mail: irawanferryirawan@yahoo.com
}

\begin{abstract}
ABSTRAK
Pembentukan peraturan perundang-undangan merupakan syarat dalam rangka pembangunan hukum nasional yang hanya dapat terwujud apabila didukung oleh metode yang baik, yang mengikat semua lembaga yang berwenang membuat peraturan perundang-undangan. Indonesia merupakan negara hukum yang mempunyai kewajiban melaksanakan pembangunan hukum nasional yang baik, yang dilakukan secara terencana, terpadu dan berkelanjutan dalam sistem hukum nasional. Konsep pembentukan peraturan perundang-undangan di Indonesia meliputi beberapa konsep yaitu konsep pembentukan peraturan perundang-undangan harus sesuai dengan konsep negara hukum Pancasila. Selain itu, konsep pembentukan peraturan perundang-undangan yang baik harus mengedepankan perlindungan Hak Asasi Manusia. Konsep pembentukan peraturan perundang-undangan yang baik harus mengedepankan asas equality before the law. Konsep pembentukan peraturan perundang-undangan yang baik harus sesuai dengan asas-asas pembentukan peraturan perundang-undangan yang telah ditetapkan sebelumnya oleh undangundang. Untuk selanjutnya, konsep pembentukan perundang-undangan dibentuk oleh pemegang kekuasaan yang sah, yang dipilih oleh rakyat secara demokrasi.
\end{abstract}

Kata Kunci: konsep, peraturan perundang-undangan.

\section{ABSTRACT}

Formation of the legislation is a requirement in the development of national law which can only be achieved if supported by a good method, which is binding on all institutions authorized to make Regulations. Indonesia is a country that has a legal obligation to carry out the development of a good national law, which is done in a planned, sustainable, and integrated into the national legal system. The concept of the establishment of laws and regulations in Indonesia includes several concepts, namely the concept of the establishment of legislation must be in accordance with State law concept of Pancasila. In addition, the concept of the establishment of legislation that either must prioritize the protection of Human Rights. The concept of the establishment of legislation that both must put forward the principle of equality before the law. The concept of the establishment of legislation that either should be in accordance with the principles of the formation of legislation predetermined by law. Henceforth, the concept of the establishment of law established by legal authority, elected by the people in a democracy.

Keywords: concept, legislation.

\section{PENDAHULUAN}

Negara Indonesia adalah negara hukum. Dengan sebutan sebagai negara hukum, Indonesia memiliki aturan-aturan hukum yang berbentuk perundangundangan. Bentuk peraturan perundang-undangan ini berfungsi untuk mengatur masyarakat ke arah yang lebih baik lagi. Dalam membentuk suatu peraturan perundang-undangan, tentunya membutuhkan suatu konsep dalam rencana untuk membentuk suatu peraturan perundang-undangan yang baik. Peraturan perundang-undangan yang baik yaitu suatu peraturan perundang-undangan yang memiliki dasar atau landasan yang disebut dengan Grundnorm.

Bagi bangsa Indonesia, Grundnorm merupakan landasan bagi pembentukan peraturan perundangundangan. Grundnorm merupakan pondasi bagi terbentuknya hukum yang memiliki keadilan. Pancasila merupakan Grundnorm bagi bangsa Indonesia. Pancasila menjadi sumber dari segala 
sumber hukum di Indonesia. Oleh sebab itu, jika pembentukan peraturan perundang-undangan di Indonesia tidak sesuai dengan Pancasila, maka peraturan perundang-undangan belum memiliki dasar yang kuat untuk diundangkan. Dengan demikian, peraturan perundang-undangan belum memenuhi konsep dalam pembentukan peraturan perundangundangan yang ada.

Membentuk suatu peraturan perundangundangan tentunya membutuhkan rencana atau plan yang baik untuk menentukan ke arah mana peraturan perundang-undangan tersebut dibentuk. Dengan rencana yang baik, maka akan terbentuk pula suatu peraturan perundang-undangan yang baik. Dalam merencanakan pembentukan peraturan perundangundangan, tentunya tidak lepas dengan apa yang disebut dengan konsep. Konsep inilah yang nantinya memiliki peran aktif dalam membentuk peraturan perundang-undangan yang baik. Dapat membentuk suatu peraturan perundang-undangan yang memiliki kepastian, keadilan, dan manfaat.

Pembentukan peraturan perundang-undangan tentunya membutuhkan konsep sebagai modal awal dalam membentuk peraturan perundang-undangan yang baik. Konsep inilah yang nantinya akan mengarahkan perturan perundang-undangan yang dibentuk menjadi peraturan perundang-undangan yang baik, yang terarah, yang memiliki keadilan, kepastian dan dapat mendistribusikan manfaat. Negara Kesatuan Republik Indonesia (selanjutnya disingkat NKRI) merupakan negara hukum yang membutuhkan konsep dalam membentuk hukum. Hukum yang berlaku, jika dibentuk dengan menggunakan konsep yang baik, yang terencana dengan baik, maka hukum yang berupa peraturan perundang-undangan yang dimiliki oleh NKRI akan menjadi hukum yang baik yang mencerminkan keadilan. oleh karena itu, konsep pembentukan peraturan perundang-undangan merupakan hal yang sangat penting dalam membentuk suatu peraturan perundang-undangan yang baik.

Konsep pembentukan peraturan perundangundangan di Indonesia harus benar-benar sesuai dengan norma dasar serta asas-asas dalam pembentukan peraturan perundang-undangan. Dengan demikian, pembentukan peraturan perundang-undangan akan membentuk hukum yang sesuai dengan cita hukum bangsa Indonesia itu sendiri dengan mengedepankan konsep yang baik dalam membentuk suatu peraturan perundang-undangan yang baik, yang mampu mengatur, menjaga dan melindungi seluruh masyarakat, bangsa dan negara Indonesia.

\section{METODE PENELITIAN}

Penelitian ini menggunakan tipe penelitian normatif dengan pendekatan masalah conseptual approach yang mengaji konsep-konsep dan asas-asas dalam pembentukan peraturan perundang-undangan, diantaranya adalah asas equality before the law, konsep negara hukum pancasila.

\section{PEMBAHASAN \\ Asas-Asas Pembentukan Peraturan Perundang- undangan}

Pembentukan peraturan perundang-undangan bertujuan untuk membentuk suatu peraturan perundang-undangan yang baik. Dalam menyusun peraturan perundang-undangan yang baik menurut I.C. Van Der Vlies dan A. Hamid S. Attamimi dibagi menjadi 2 (dua) klasifikasi, yaitu asas-asas yang formal dan asas-asas yang material. Asas-asas yang formal meliputi: asas tujuan yang jelas atau beginsel van duideleijke doelstelling; asas organ/lembaga yang tepat atau beginsel van het juiste orgaan; asas perlunya pengaturan atau het noodzakelijkheids beginsel; asas dapatnya dilaksanakan atau het beginsel van uitvoerbaarheid; asas konsensus atau het beginsel van consensus.

Sedangkan asas-asas materiil antara lain meliputi: asas tentang terminologi dan sistematika yang benar atau het beginsel van duidelijke terminologi en duidelijke systematiek; asas tentang dapat dikenali atau het beginsel van de kenbaarheid; asas perlakuan yang sama dalam hukum atau het rechtsgelijkheidsbeginsel; asas kepastian hukum atau het rechtszekerheids beginsel; asas pelaksanakan hukum sesuai keadaan individual atau het beginsel van de individuele rechtbedeling. ${ }^{1}$

Pendapat Maria Farida di atas, jika dihubungkan pembagian atas asas formal dan materiil yang sesuai dengan asas negara hukum di Indonesia, maka pembagiannya dapat dikelompokkan. Maksud asasasas formal meliputi asas tujuan yang jelas, asas perlunya pengaturan, asas organ atau lembaga yang tepat, asas materi muatan yang tepat, asas dapat

\footnotetext{
${ }^{1}$ Maria Farida Indrati Soeprapto, Ilmu Perundangundangan: Jenis, Fungsi, dan Materi Muatan, Kanisius, Yogyakarta, 2010, h. 228.
} 
dilaksanakan, dan asas dapat dikenali. Sedangkan yang termasuk ke dalam asas-asas materiil yaitu, asas sesuai dengan cita hukum Indonesia dan norma fundamental negara, asas sesuai dengan hukum dasar negara, asas sesuai dengan prinsip negara berdasarkan hukum, dan asas sesuai dengan prinsip pemerintahan berdasarkan konstitusi.

Dalam membentuk peraturan perundangundangan harus dilakukan berdasarkan asas pembentukan peraturan perundang-undangan yang baik meliputi: kejelasan tujuan, kelembagaan atau pejabat pembentuk yang tepat dan kesesuaian antara jenis, hierarki serta materi muatan yang dapat dilaksanakan dan kedayagunaan serta kehasilgunaan, kejelasan rumusan dan keterbukaan.

Di samping itu materi muatan yang dimuat dalam peraturan perundang-undangan harus mencerminkan asas pengayoman, kemanusiaan dan kebangsaan serta kekeluargaan, kenusantaraan, bhinneka tunggal ika, keadilan serta kesamaan kedudukan dalam hukum dan pemerintahan, ketertiban dan kepastian hukum serta keseimbangan, keserasian, dan keselarasan.

Asas-asas pembentukan peraturan perundangundangan di atas mencerminkan bentuk peraturan perundang-undangan yang baik. Jika itu diterapkan ke dalam suatu peraturan perundang-undangan, maka akan terbentuk suatu peraturan perundangundangan yang baik yang sesuai dengan asas-asas yang sudah tercantum di dalam undang-undang tanpa meninggalkan prinsip-prinsip keadilan.

Sedangkan A. Hamid S. Attamimi berpendapat mengenai pembentukan peraturan perundangundangan yang baik. Pendapat Attamimi menyebutkan bahwa, pembentukan peraturan perundang-undangan Indonesia yang patut, adalah sebagai berikut: Cita Hukum Indonesia; Asas Negara Berdasar Atas Hukum dan Asas Pemerintahan yang berdasar Konstitusi; Asas-asas lainnya. ${ }^{2}$

Pembentukan peraturan perundang-undangan harus mengutamakan kejelasan tujuan, dalam arti tujuan pembentukan peraturan perundang-undangan tersebut harus jelas, memenuhi keinginan masyarakat banyak agar dapat menciptakan kepastian yang berkeadilan sehingga dapat mendistribusikan manfaat bagi seluruh rakyat Indonesia. Selain itu, konsep lembaga atau pejabat pembentuk peraturan perundang-

${ }^{2}$ Maria Farida Indrati Soeprapto, Ilmu Perundangundangan: Jenis, Fungsi, dan Materi Muatan, Kanisius, Yogyakarta, 2010, h. 228. undangan harus merupakan lembaga yang kredibel, yang diakui secara demokratis oleh masyarakat banyak. Pembentukan peraturan perundang-undangan harus menyesuaikan antara jenis, hierarki, dan materi muatan serta asas yang sesuai dengan dasar pembentukan peraturan perundang-undangan.

Asas merupakan dasar atau landasan dalam menentukan sikap dan perilaku. Asas-asas pembentukan peraturan perundang-undangan merupakan dasar pijak bagi pembentukan peraturan perundang-undangan dan penentu kebijakan dalam membentuk peraturan perundang-undangan. Semua asas-asas harus terpateri dalam diri penentu kebijakan yang akan membentuk peraturan perundangundangan. Di dalam pembentukan peraturan perundang-undangan tentunya membutuhkan asas atau dasar dalam membentuk suatu peraturan perundang-undangan.

Dalam pembentukan peraturan perundangundangan NKRI yang berasaskan Pancasila sebagai dasar fundamentalnya. Konsep negara hukum Pancasila merupakan konsep negara hukum asli dari Indonesia menjadi asas yang utama dalam pembentukan peraturan perundang-undangan di Indonesia. Konsep negara hukum Pancasila berperan penting dalam mewujudkan peraturan perundangundangan di Indonesia.

Asas yang di adopsi dari konsep negara hukum Pancasila memiliki kebenaran yang telah diakui oleh bangsa Indonesia sejak dulu sampai sekarang. Konsep negara hukum Pancasila sudah tidak diragukan lagi kebenarannya dalam mewujudkan asas pembentukan peraturan perundang-undangan di Indonesia. Asas dalam konsep negara hukum Pancasila dapat dijabarkan dan direalisasikan menjadi asas-asas pembentukan peraturan perundangundangan yang baik, yang menciptakan kepastian, keadilan, dan manfaat bagi seluruh rakyat Indonesia. Asas pembentukan peraturan perundang-undangan harus menganut asas-asas pembentukan peraturan perundang-undangan yang baik sesuai dengan prinsip-prinsip keadilan. Asas merupakan norma yang harus terwujud dalam peraturan perundang-undangan dan yang berlaku memaksa. Asas-asas pembentukan peraturan perundang-undangan yang baik antara lain adalah: Peraturan perundang-undangan tidak berlaku surut; Peraturan perundang-undangan yang dibuat oleh penguasa yang lebih tinggi, mempunyai kedudukan yang lebih tinggi, hal ini sesuai dengan 
hierarki perundang-undangan; Peraturan perundangundangan yang bersifat khusus menyampingkan peraturan perundang-undangan yang bersifat umum; Peraturan perundang-undangan yang berlaku belakangan membatalkan peraturan perundangundangan yang berlaku terdahulu; Peraturan perundang-undangan tidak dapat di ganggu gugat, dalam arti undang-undang merupakan cerminan dari keadilan yang harus diakui kebenarannya oleh semua pihak; dan Peraturan perundang-undangan sebagai sarana untuk semaksimal mungkin dapat mencapai kesejahteraan spiritual dan material bagi masyarakat maupun individu termasuk sebagai sarana untuk memperoleh keadilan. ${ }^{3}$

Asas-asas pembentukan peraturan perundangundangan dapat dibagi menjadi dua asas, yaitu asas formal dan asas materiil. Asas-asas formal mencakup asas tujuan yang jelas demi keadilan, asas lembaga yang tepat untuk membentuk undang-undang, asas perlu pengaturan, asas dapat dilaksanakan, dan asas konsensus. Sedangkan yang masuk asas materiil adalah asas terminologi dan sistematika yang benar, asas dapat dikenali, asas perlakuan yang sama dalam hukum, asas kepastian hukum, dan asas pelaksanaan hukum sesuai dengan keadaan individual.

Dalam membentuk peraturan perundangundangan harus dilakukan berdasarkan asas pembentukan peraturan perundang-undangan yang baik meliputi kejelasan tujuan dalam membentuk peraturan perundang-undangan, kelembagaan atau pejabat pembentuk yang tepat yang merupakan lembaga kredibel yang dipilih secara demokrasi oleh rakyat selaku pemegang kekuasaan negara, kesesuaian antara jenis, hierarki, dan materi muatan, dapat dilaksanakan, kedayagunaan dan kehasilgunaan, kejelasan rumusan, dan keterbukaan.

Materi muatan yang dimuat dalam peraturan perundang-undangan harus mencerminkan asas pengayoman, kemanusiaan, kebangsaan, kekeluargaan, kenusantaraan, bhinneka tunggal ika, keadilan, kesamaan kedudukan dalam hukum dan pemerintahan, ketertiban dan kepastian hukum, dan/atau keseimbangan, keserasian, dan keselarasan. Pembentukan peraturan perundang-undangan Indonesia yang baik harus mengedepankan cita hukum Indonesia dalam mengambil gagasan untuk terwujudnya kepastian yang berkeadilan. Selain

${ }^{3}$ Van de Vlies, Handboek Wetgeving, Tjeenk Willink, Zwolle, 1987, h. 175. itu, asas negara yang berdasar atas hukum menjadi landasan yang patut bagi terciptanya perundangundangan yang baik.

Sebagai negara hukum yang mempunyai jenjang hukum, harus mementingkan hierarki perundangundangan dalam pembentukan peraturan perundangundangan terutama konstitusi sebagai hukum tertinggi. Dalam pembentukan peraturan perundangundangan di Indonesia harus berpedoman beberapa hal sebagai berikut. Pertama adalah ideologi bangsa yaitu Cita Hukum Indonesia yang tidak lain melainkan Pancasila. Kedua adalah Norma Fundamental Negara juga tidak lain melainkan Pancasila. Ketiga adalah asas-asas negara berdasar atas hukum dan asas-asas pemerintahan berdasar konstitusi.

Selain ketiga pedoman yang telah tersebut, ada beberapa prinsip-prinsip yang digunakan dalam pembentukan peraturan perundang-undangan yang meliputi, dasar peraturan perundang-undangan selalu menggunakan peraturan perundang-undangan sebagai acuan pembentukan peraturan perundangundangan, hanya peraturan perundang-undangan tertentu saja yang dapat dijadikan landasan yuridis bagi pembentukan peraturan perundang-undangan, peraturan perundang-undangan yang masih berlaku hanya dapat dihapus, dicabut atau diubah oleh peraturan perundang-undangan yang sederajat atau peraturan perundang-undangan yang lebih tinggi, dan peraturan perundang-undangan yang baru mengesampingkan perundang-undangan lama atau Lex posterior derogat legi priori.

Asas pembentukan peraturan Perundangundangan yang baik, meliputi: ${ }^{4}$

Pertama, Asas kejelasan tujuan, asas ini mengartikan bahwa setiap Pembentukan Peraturan Perundang-undangan harus mempunyai tujuan yang jelas yang hendak dicapai;

Kedua, Asas kelembagaan atau pejabat pembentuk yang tepat, asas ini mengartikan bahwa setiap jenis Peraturan Perundang-undangan harus dibuat oleh lembaga negara atau pejabat Pembentuk Peraturan Perundang-undangan yang berwenang, Peraturan Perundang-undangan tersebut dapat dibatalkan atau batal demi hukum apabila dibuat oleh lembaga negara atau pejabat yang tidak berwenang;

Ketiga, Asas kesesuaian antara jenis, hierarki, dan materi muatan, asas ini mengartikan bahwa dalam

\footnotetext{
${ }^{4}$ Pasal 5 Undang-Undang Nomor 12 Tahun 2011 tentang Pembentukan Peraturan Perundang-undangan.
} 
Pembentukan Peraturan Perundang-undangan harus benar-benar memperhatikan materi muatan yang tepat sesuai dengan jenis dan hierarki Peraturan Perundangundangan;

Keempat, Asas dapat dilaksanakan, asas ini mengartikan bahwa setiap Pembentukan Peraturan Perundang-undangan harus memperhitungkan efektivitas Peraturan Perundang-undangan tersebut di dalam masyarakat, baik secara filosofis, sosiologis, maupun yuridis;

Kelima, Asas kedayagunaan dan kehasilgunaan, asas ini mengartikan bahwa setiap Peraturan Perundang-undangan dibuat karena memang benarbenar dibutuhkan dan bermanfaat dalam mengatur kehidupan bermasyarakat, berbangsa, dan bernegara;

Keenam, Asas kejelasan rumusan, asas ini mengartikan bahwa setiap Peraturan Perundangundangan harus memenuhi persyaratan teknis penyusunan Peraturan Perundang-undangan, sistematika, pilihan kata atau istilah, serta bahasa hukum yang jelas dan mudah di mengerti sehingga tidak menimbulkan berbagai macam interpretasi dalam pelaksanaannya;

Ketujuh, Asas keterbukaan, asas ini mengartikan bahwa dalam Pembentukan Peraturan Perundangundangan mulai dari perencanaan, penyusunan, pembahasan, pengesahan atau penetapan, dan pengundangan bersifat transparan dan terbuka. Oleh sebab itu, seluruh lapisan masyarakat mempunyai kesempatan yang seluas-luasnya untuk memberikan masukan dalam Pembentukan Peraturan Perundangundangan.

Materi muatan Peraturan Perundang-undangan harus mencerminkan asas pengayoman. Asas ini mengartikan bahwa setiap materi muatan Peraturan Perundang-undangan harus berfungsi memberikan pelindungan untuk menciptakan ketenteraman masyarakat. Asas kemanusiaan mengartikan bahwa setiap materi muatan Peraturan Perundang-undangan harus mencerminkan pelindungan dan penghormatan Hak Asasi Manusia serta harkat dan martabat setiap warga negara dan penduduk Indonesia secara proporsional. $^{5}$

Asas kebangsaan mengartikan bahwa setiap setiap materi muatan Peraturan Perundang-undangan harus mencerminkan sifat dan watak bangsa Indonesia yang majemuk dengan tetap menjaga prinsip Negara

\footnotetext{
5 Pasal 6 Undang-Undang Nomor 12 Tahun 2011 tentang Pembentukan Peraturan Perundang-undangan.
}

Kesatuan Republik Indonesia. Asas kekeluargaan mengartikan bahwa setiap setiap materi muatan Peraturan Perundang-undangan harus mencerminkan musyawarah untuk mencapai mufakat dalam setiap pengambilan keputusan.

Asas kenusantaraan mengartikan bahwa setiap setiap materi muatan Peraturan Perundangundangan senantiasa memperhatikan kepentingan seluruh wilayah Indonesia dan setiap materi muatan Peraturan Perundang-undangan yang dibuat di daerah merupakan bagian dari sistem hukum nasional yang berdasarkan Pancasila dan Undang-Undang Dasar Negara Republik Indonesia Tahun 1945. Asas Bhinneka Tunggal Ika mengartikan bahwa setiap materi muatan Peraturan Perundang-undangan harus memperhatikan keragaman penduduk, agama, suku dan golongan, kondisi khusus daerah serta budaya dalam kehidupan bermasyarakat, berbangsa, dan bernegara.

Asas keadilan mengartikan bahwa setiap setiap materi muatan Peraturan Perundang-undangan harus mencerminkan keadilan secara proporsional bagi setiap warga negara, keadilan yang sesuai dengan norma dasar bangsa. Asas kesamaan kedudukan dalam hukum dan pemerintahan mengartikan bahwa setiap setiap materi muatan Peraturan Perundang-undangan tidak boleh memuat hal yang bersifat membedakan berdasarkan latar belakang, antara lain, agama, suku, ras, golongan, gender, atau status sosial. Asas ketertiban dan kepastian hukum mengartikan bahwa setiap setiap materi muatan Peraturan Perundangundangan harus dapat mewujudkan ketertiban dalam masyarakat melalui jaminan kepastian.

Asas keseimbangan dan keserasian mengartikan bahwa setiap setiap materi muatan Peraturan Perundang-undangan harus mencerminkan keseimbangan dan keserasian antara kepentingan perorangan (individu), masyarakat dan kepentingan bangsa dan negara, dan yang terakhir adalah asas lain sesuai dengan bidang hukum Peraturan Perundangundangan yang bersangkutan.

Setelah memenuhi asas-asas peraturan perundangundangan, bentuk peraturan perundang-undangan dapat dilaksanakan dalam arti peraturan perundangundangan yang telah dibentuk dapat diterapkan dan dilaksanakan sebagai landasan hukum bagi negara hukum yang menjunjung tinggi supremasi hukum. Konsep selanjutnya berkaitan dengan manfaat yaitu kedayagunaan dan kehasilgunaan perundang- 
undangan yang dibentuk harus memberikan manfaat. Kejelasan rumusan dalam substansi peraturan perundang-undangan merupakan konsep dasar dalam membentuk peraturan perundang-undangan yang baik dan yang terakhir adalah keterbukaan konsep hukum yang diatur di dalam peraturan perundangundangan diketahui dan diakui kebenarannya oleh seluruh masyarakat yang menjadi subyek dari hukum.

Konsep muatan peraturan perundang-undangan harus mampu memberikan pengayoman bagi manusia Indonesia pada umumnya. Mementingkan kehidupan berbangsa dan bernegara mengandung prinsip kekeluargaan serta ke-bhinneka tunggal ikaan yang memunculkan keadilan berdasar Pancasila sebagai falsafah dan ideologi bangsa Indonesia yang memberikan perlindungan hukum kepada seluruh rakyat Indonesia dengan menganut asas persamaan di hadapan hukum.

Konsep keadilan diharapkan memberikan realisasi bagi keadilan hukum yang diterima oleh masyarakat. Keadilan hukum dapat diterima masyarakat jika pembentukan hukum menganut prinsip-prinsip dan nilai-nilai keadilan dalam pembentukannya. Keadilan yang memiliki prinsip-prinsip keadilan yang baik yaitu keadilan berupa nilai-nilai yang memberikan kesamaan bagi seluruh rakyat Indonesia tanpa memandang jasa dan keadaan status sosial warga negara. Keadilan dari nilai-nilai Pancasila kemudian direalisasikan ke dalan norma hukum dan menjadi suatu keadilan yang dapat diakui kebenarannya karena pembentukan peraturan perundang-undangan dibentuk dengan cara yang adil.

Konsep dasar peraturan perundang-undangan yang berdasarkan Pancasila, mengedepankan Hak Asasi Manusia termasuk hak keadilan bagi warga negara serta memberikan persamaan di hadapan hukum bagi seluruh rakyat Indonesia. Konsep ini tentunya menjadi pedoman bagi pembentukan peraturan perundang-undangan yang baik bagi bangsa dan negara Indonesia, menciptakan kepastian yang mengadopsi nilai-nilai Pancasila sehingga dapat mendistribusikan manfaat bagi seluruh rakyat Indonesia. Keadilan akan terwujud jika selalu mengedepankan Hak Asasi Manusia yang bersumber dari Pancasila yang berupa prinsip-prinsip keadilan.

Pembentukan peraturan perundang-undangan yang baik akan mengikuti dasar yang diberikan oleh cita negara hukum yaitu Pancasila. Jika Pancasila dihubungkan dengan pembagian atas asas formal dan materiil, maka pembagiannya dapat disimpulkan sebagai asas-asas formal sesuai dengan Pancasila meliputi asas tujuan yang jelas, asas perlunya pengaturan, asas organ atau lembaga yang tepat, asas materi muatan yang tepat, asas dapat dilaksanakan, dan asas dapat dikenali. Sedangkan asas-asas materiilnya meliputi asas sesuai dengan cita hukum Indonesia dan norma fundamental negara, asas sesuai dengan hukum dasar negara, asas sesuai dengan prinsip negara berdasarkan hukum, serta asas sesuai dengan prinsip pemerintahan berdasarkan konstitusi.

\section{Konsep-konsep Pembentukan Peraturan Perundang-undangan}

Konsep pembentukan peraturan perundangundangan merupakan rencana atau plan dalam membentuk hukum. Hukum pada hakekatnya adalah produk penilaian akal-budi yang berakar dalam hati nurani manusia tentang keadilan berkenaan dengan perilaku manusia dan situasi kehidupan manusia. Penghayatan tentang keadilan memunculkan penilaian bahwa dalam situasi kemasyarakatan tertentu, orang seyogyanya berperilaku dengan cara tertentu, karena hal itu adil atau memenuhi rasa keadilan. ${ }^{6}$

Keadilan merupakan nilai abstrak yang perlu perwujudan dalam bentuk norma hukum sebagai sarana untuk mewujudkan nilai-nilai tersebut dalam kehidupan bermasyarakat. ${ }^{7}$ Perwujudan nilai-nilai norma hukum dalam masyarakat terbentuk melalui aturan perundang-undangan. Aturan perundangundangan yang dibentuk harus memenuhi rasa keadilan. Menurut Sajipto Rahardjo, dalam proses pembuatan rancangan undang-undang harus memperhatikan peran dari asas hukum. Sistem hukum termasuk peraturan perundang-undangan yang dibangun tanpa asas hukum hanya akan berupa tumpukan undang-undang. Asas hukum memberikan arah yang dibutuhkan. Di waktu-waktu yang akan datang masalah dan bidang yang diatur pasti semakin bertambah. Maka pada waktu hukum atau undangundang dikembangkan, asas hukum memberikan tuntunan dengan cara bagaimana dan ke arah mana sistem tersebut akan dikembangkan. ${ }^{8}$

\footnotetext{
${ }^{6}$ Bernard Arief Sidharta, Ilmu Hukum Indonesia, FH Unika Parahyangan, Bandung, 2010, h. 88.

${ }^{7}$ Mahmutarom HR., Rekonstruksi Konsep Keadilan, Badan Penerbit Undip, Semarang, h. 119.

${ }^{8}$ Sajipto Rahardjo, Sisi-sisi Lain dari Hukum di Indonesia, Penerbit Buku Kompas, Jakarta, 2006, h. 140.
} 
Dalam kenyataan empiris telah terbukti bahwa suatu undang-undang, bahkan kodifikasi, tidak akan pernah lengkap dalam mengatur segala persoalan yang terjadi maupun yang akan terjadi di tengah-tengah dinamika perkembangan masyarakat. ${ }^{9}$ Pembentukan perundang-undangan belum sesuai dengan Pancasila dikarenakan masih banyak perbedaan paradigma tentang Pancasila dan perdebatan-perdebatan tentang kebenaran Pancasila sehingga jelas, pembentukan peraturan perundang-undangan tidak akan sesuai dengan substansi Pancasila yang mencerminkan keadilan. Terbukti banyaknya judicial review terhadap produk Undang-Undang yang telah diundangkan dalam Lembaran Negara Republik Indonesia. Diperlukannya persamaan visi, misi, tujuan dan persepsi dalam memahami Pancasila sebagai sumber dari segala sumber hukum.

Salah satu hal yang penting dalam sebuah pemerintahan, baik dalam tingkat nasional maupun daerah adalah pembentukan produk hukum yang sangat diperlukan karena diperlukan untuk merespon kepentingan masyarakat. Dalam membentuk hukum, diperlukan pedoman sehingga produk hukum yang diterbitkan nantinya akan kuat demi hukum dan dapat diimplementasikan di kemudian hari. Berawal dengan dibentuknya Undang-Undang Nomor 10 Tahun 2004 tentang Pembentukan Peraturan PerundangUndangan yang kemudian disempurnakan dengan Undang-Undang Nomor 12 Tahun 2011 tentang Pembentukan Peraturan Perundang-undangan dan diundangkan pada tanggal 12 Agustus 2011, maka setiap pembentukan produk hukum mempunyai dasar dan pedoman. Pembentukan Undang-Undang Nomor 12 Tahun 2011 tentang Pembentukan Peraturan Perundang-undangan tersebut merupakan pelaksanaan perintah Pasal 22 A Undang-Undang Dasar Negara Republik Indonesia Tahun 1945.

Pembentukan undang-undang ini didasarkan pada pemikiran bahwa negara Indonesia merupakan negara hukum. Sebagai negara hukum, segala aspek kehidupan dalam bidang kemasyarakatan, kebangsaan, dan kenegaraan harus berdasarkan sistem hukum nasional. Undang-Undang Nomor 12 Tahun 2011 adalah dasar hukum bagi pembentukan peraturan perundang-undangan baik di tingkat pusat maupun daerah. Undang-undang ini dibentuk

9 Basuki Rekso Wibowo, "Peranan Hakim dalam Pembangunan Hukum", Pro Justitia, Fakultas Hukum Universitas Parahyangan, Tahun XV, Nomor 4, Oktober 1997, h. 62. untuk menciptakan tertib pembentukan peraturan perundang-undangan, agar konsepsi dan perumusan normanya mantap, bulat, dan harmonis, tidak saling bertentangan, dan tumpang tindih satu sama lain. Melalui undang-undang tersebut, diharapkan semua lembaga yang berwenang membentuk peraturan perundang-undangan memiliki pedoman khusus yang baku dan terstandarisasi dalam proses dan metode membentuk peraturan perundang-undangan secara terencana, terpadu, dan sistematis.

Pembentukan peraturan perundang-undangan merupakan syarat dalam rangka pembangunan hukum nasional yang hanya dapat terwujud apabila didukung oleh metode yang baik, yang mengikat semua lembaga yang berwenang membuat peraturan perundangundangan. Indonesia merupakan negara hukum yang mempunyai kewajiban melaksanakan pembangunan hukum nasional yang baik, yang dilakukan secara terencana, terpadu dan berkelanjutan dalam sistem hukum nasional. Sistem hukum tersebut diharapkan dapat menjamin perlindungan hak dan kewajiban segenap rakyat Indonesia dengan berdasarkan pada Pancasila dan Undang-Undang Dasar 1945.

Pemenuhan kebutuhan masyarakat atas peraturan perundang-undangan yang baik tidak luput dari bagaimana pembuatan suatu UndangUndang dilakukan dengan metode yang baik pula. Peraturan Perundang-undangan tersebut mempunyai peranan yang sangat penting dalam pembangunan hukum di Indonesia karena fungsinya adalah untuk mewujudkan ketertiban masyarakat dan kepastian hukum serta keadilan bagi seluruh rakyat Indonesia.

Dalam membentuk dan menerapkan sebuah peraturan perundangan di pegang beberapa prinsip: Pertama, Peraturan yang lebih tinggi mengalahkan peraturan yang lebih rendah atau Asas lex superior derogat legi inferiori, apabila terjadi konflik atau pertentangan antara peraturan perundang-undangan yang tinggi dengan yang rendah maka yang tinggilah yang harus didahulukan. Kedua, Peraturan yang lebih baru mengalahkan peraturan yang lebih lama atau Lex posterior derogat legi priori adalah asas penafsiran hukum yang menyatakan bahwa hukum yang terbaru atau posterior mengesampingkan hukum yang lama atau prior. Asas ini biasanya digunakan baik dalam hukum nasional maupun internasional. Ketiga, Peraturan yang mengatur masalah khusus mengalahkan peraturan yang bersifat umum atau Lex specialis derogat legi generali adalah asas penafsiran 
hukum yang menyatakan bahwa hukum yang bersifat khusus atau lex specialis mengesampingkan hukum yang bersifat umum atau lex generalis;

Pembentukan peraturan perundang-undangan yang baik harus memenuhi kriteria-kriteria yang terkandung di dalam nilai-nilai Pancasila yaitu prinsipprinsip keadilan dalam Pancasila. Mendasarkan pendapat Lili Rasidji, dalam pelaksanaan perundangundangan yang bertujuan untuk pembaharuan itu dapat berjalan sebagaimana mestinya, hendaknya perundang-undangan yang dibentuk itu sesuai dengan apa yang menjadi inti pemikiran aliran sociological Jurisprudence yaitu hukum yang baik hendaknya sesuai dengan hukum yang hidup di dalam masyarakat. ${ }^{10}$

Hukum yang hidup dalam masyarakat digali dan dirumuskan menjadi sebuah dasar Negara yaitu Pancasila. Oleh karena itu seperti pendapat Rasidji, hukum yang baik harus mencerminkan nilai-nilai yang terkandung dalam Pancasila yang merupakan adaptasi nilai yang bersumber dari hukum yang hidup di dalam masyarakat. Pancasila merupakan satusatunya pedoman dasar bagi bangsa Indonesia dalam membentuk hukum yang baik yang memberikan keadilan bagi seluruh rakyat Indonesia, dengan kata lain, keadilan diwujudkan dalam bentuk kepastian hukum yang mengadopsi nilai-nilai yang terkandung di dalam Pancasila yang berupa prinsip-prinsip keadilan.

Dasar pembentukan peraturan perundangundangan muncul dari prinsip dan nilai yang diambil dari Pancasila sebagai Staatfundamentalnorm bangsa Indonesia, mengadopsi dari nilai-nilai Pancasila yang lahir dari bangsa Indonesia itu sendiri yang digagas oleh Founding Father/Mother Bangsa Indonesia. Hal ini memberikan landasan bagi terwujudnya suatu peraturan perundang-undangan yang baik. Prinsip dan nilai dari Pancasila mencerminkan perlindungan terhadap Hak Asasi Manusia dengan tujuan terciptanya keadilan.

Berdasar teori negara hukum, tentunya bangsa Indonesia harus mengedepankan supremasi hukum guna terwujudnya keadilan. Keadilan dalam kaitannya dengan pembentukan peraturan perundangundangan tidak dapat dipisahkan karena tujuan dari hukum itu sendiri untuk memberikan keadilan. Dalam teori perundang-undangan, pembentukan

${ }^{10}$ Lili Rasjidi dan Ira Thania Rasjidi, Pengantar Filsafat Hukum, Mandar Maju, Bandung, 2002, h. 74. perundang-undangan yang baik harus berpedoman pada Staatfundamentalnorm yaitu Pancasila. Dasar dari pembentukan peraturan perundang-undangan tersebut mengadopsi prinsip dan nilai-nilai Pancasila guna terwujudnya keadilan bagi seluruh rakyat Indonesia yaitu perlindungan Hak Asasi Manusia dalam memperoleh keadilan.

Pembentukan peraturan perundang-undangan sebagai bagian dari konsep politik hukum berada dalam ruang lingkup nilai. Nilai tidak dapat dipisahkan dalam pembentukan peraturan perundangundangan. Nilai-nilai yang berasal dari aspek sosial, budaya, politik, ekonomi, hukum, dan sebagainya saling berinteraksi dan saling mempengaruhi satu sama lainnya dan merupakan satu kesatuan dalam membentuk perundang-undangan.

Dalam negara hukum, konsep yang tepat adalah mengedepankan hak asasi manusia. Pembentukan peraturan perundang-undangan harus sesuai dengan konsep negara hukum Pancasila yang mencerminkan prinsip-prinsip keadilan yang di dalamnya menganut perlindungan HAM. Pancasila mempunyai perbedaan dengan norma dasar yang lainnya yaitu Pancasila menganut prinsip non sekuler dalam menciptakan kepastian, keadilan, dan manfaat.

Pancasila berasal dari NKRI sedangkan norma dasar yang ada menganut sistem barat yaitu dengan prinsip negara sekuler. Konsep negara hukum yang mencerminkan keadilan yang harus dianut oleh bangsa Indonesia adalah konsep negara hukum Pancasila yang memberikan keadilan berupa prinsip-prinsip keadilan berdasarkan Pancasila. Pancasila merupakan staatfundamentalnorm bagi bangsa Indonesia. Dalam membentuk suatu peraturan perundang-undangan yang baik adalah dengan menganut prinsip-prinsip yang terkandung di dalam nilai-nilai Pancasila.

Dalam pembentukan suatu peraturan perundangundangan yang baik harus memenuhi beberapa konsep. Konsep pembentukan peraturan perundangundangan harus sesuai dengan konsep negara hukum Pancasila yaitu merealisasikan prinsip-prinsip keadilan berupa nilai-nilai yang terkandung di dalam Pancasila ke dalam norma hukum, penjelasan tentang konsep tersebut, mengharuskan nilai-nilai Pancasila yang mengandung kebenaran tentang keadilan harus direalisasikan ke dalam norma hukum yang menghasilkan kepastian, keadilan, dan manfaat. Kepastian hukum akan berdiri seimbang dengan keadilan karena kepastian hukum sudah mengadopsi 
nilai-nilai kebenaran tentang keadilan Pancasila. Oleh sebab itu, distribusi manfaat akan tercapai sesuai dengan cita hukum bangsa Indonesia.

Konsep pembentukan peraturan perundangundangan yang baik harus mengedepankan perlindungan Hak Asasi Manusia terutama perlindungan hak dalam memperoleh keadilan. Konsep pembentukan peraturan perundang-undangan harus mengedepankan perlindungan Hak Asasi Manusia karena hukum ada dari manusia dan untuk manusia sebagai subyek hukum. Hukum dibentuk untuk manusia sehingga Hak Asasi Manusia harus diwujudkan dalam perlindungannya yang dilakukan oleh hukum. Pembentukan peraturan perundangundangan yang baik tentunya mengedepankan Hak Asasi Manusia agar kepastian hukum memberikan perlindungan terhadap hak-hak asasi termasuk perlindungan terhadap hak dalam memperoleh keadilan. Di dalam nilai-nilai Pancasila, Hak Asasi Manusia tercermin dari sila ketiga yaitu kemanusiaan yang adil dan beradab. Memanusiakan manusia sebagai makhluk yang beradab sebagai manusia dan memberikan keadilan seluas-luasnya bagi manusia dalam perlindungan hak dan kewajibannya yang dilakukan oleh negara.

Konsep pembentukan peraturan perundangundangan yang baik harus mengedepankan persamaan di hadapan hukum sesuai dengan asas equality before the law. Persamaan di hadapan hukum merupakan hak bagi manusia dalam memperoleh keadilan hukum. Hukum tidak memandang strata sosial seseorang di dalam hukum, akan tetapi hukum harus memberikan persamaan bagi semua manusia dalam memperoleh keadilan. Pembentukan peraturan perundang-undangan tentunya harus mengedepankan persamaan di hadapan hukum karena hukum dibentuk untuk melindungi manusia dari kesewenangwenangan sehingga dalam proses perlindungannya, hukum tidak memandang kondisi strata sosial seseorang dalam memperoleh perlindungan hukum. Pembentukan peraturan perundang-undangan jika mengedepankan asas equality before the law akan mewujudkan peraturan perundang-undangan yang mampu melindungi seluruh rakyat Indonesia dalam memperoleh perlindungan hukum termasuk perlindungan dalam memperoleh keadilan.

Konsep pembentukan peraturan perundangundangan yang baik harus sesuai dengan asas-asas pembentukan peraturan perundang-undangan yang telah ditetapkan sebelumnya oleh undang-undang. Asas-asas pembentukan peraturan perundangundangan merupakan asas yang digunakan dalam membentuk suatu aturan perundang-undangan. Pembentukan peraturan perundang-undangan sudah menjadi kewajiban dalam pembentukannya untuk menggunakan asas-asas peraturan perundangundangan agar peraturan perundang-undangan yang dibentuk mempunyai kepastian yang memiliki keadilan dan manfaat bagi orang banyak. Asas-asas peraturan perundang-undangan merupakan landasan bagi terbentuknya peraturan perundang-undangan yang baik, jika suatu peraturan perundang-undangan dibentuk dengan mengindahkan asas-asas peraturan perundang-undangan tersebut, maka peraturan perundang-undangan tidak akan memberikan tujuan hukum yang baik, tidak memberikan keadilan dan manfaat bagi orang banyak. Oleh karena itu, asas-asas peraturan perundang-undangan sangat dibutuhkan dalam membentuk peraturan perundang-undangan.

Pembentukan peraturan perundang-undangan harus dibuat oleh lembaga yang kredibel yang dipilih secara demokrasi oleh rakyat Indonesia. Lembaga kredibel ini meliputi pemegang kekuasaan yang mempunyai kewenangan untuk membentuk peraturan perundang-undangan. Berdasar modal demokrasi, maka konsep pembentukan perundang-undangan dibentuk oleh pemegang kekuasaan yang sah, yang dipilih oleh rakyat, dan dengan mandat yang sah dari rakyat memiliki kewenangan untuk membentuk peraturan perundang-undangan, sehingga peraturan perundang-undangan yang dibentuk memiliki kekuatan hukum yang sah yang diakui oleh seluruh masyarakat dalam memberikan kepastian, keadilan, dan manfaat.

\section{PENUTUP \\ Kesimpulan}

Konsep pembentukan peraturan perundangundangan di Indonesia meliputi beberapa konsep yaitu konsep pembentukan peraturan perundang-undangan harus sesuai dengan konsep Negara Hukum Pancasila. Konsep Negara Hukum Pancasila merupakan konsep dasar pembentukan peraturan perundangundangan di Indonesia, karena Pancasila merupakan Grundnorm bagi bangsa Indonesia. Selain itu, konsep pembentukan peraturan perundang-undangan yang baik harus mengedepankan perlindungan HAM 
terutama perlindungan hak dalam memperoleh keadilan.

\section{Rekomendasi}

Konsep pembentukan peraturan perundangundangan yang baik harus mengedepankan persamaan di hadapan hukum sesuai dengan asas equality before the law. Persamaan di hadapan hukum merupakan hak bagi manusia dalam memperoleh keadilan hukum. Persamaan di hadapan hukum berfungsi sebagai tolak ukur persamaan hak dalam memperoleh keadilan tanpa memandang kedudukan dan derajat seseorang. Kedudukan yang sama di hadapan hukum tentunya membutuhkan asas atau dasar dalam merealisasikan asas equality before the law tersebut. Konsep pembentukan peraturan perundang-undangan yang baik harus sesuai dengan asas-asas pembentukan peraturan perundang-undangan yang telah ditetapkan sebelumnya oleh undang-undang. Asasasas pembentukan peraturan perundang-undangan merupakan asas yang digunakan dalam membentuk suatu aturan perundang-undangan. Untuk selanjutnya, konsep pembentukan perundang-undangan dibentuk oleh pemegang kekuasaan yang sah, yang dipilih oleh rakyat secara demokrasi.

\section{DAFTAR PUSTAKA}

\section{Perundang-Undangan:}

Undang-Undang Nomor 12 Tahun 2011 tentang Pembentukan Peraturan Perundang-undangan.

\section{Buku:}

Asshiddiqie, Jimly dan M. Ali Safaat, 2006, Teori Hans Kelsen tentang Hukum, Jakarta: Sekretariat Jenderal dan Kepaniteraan Mahkamah Konstitusi RI.

Attamimi, A. Hamid S., 1990, "Peranan Keputusan Presiden Republik Indonesia dalam Penyelenggaraan Pemerintahan Negara: Studi Analisis mengenai Keputusan Presiden yang Berfungsi Pengaturan dalam Kurun Waktu PELITA I-PELITA IV', Disertasi Doktor, Jakarta, Universitas Indonesia.
Kusumaatmadja, Mochtar, 2000, Pengantar Ilmu Hukum: Suatu Pengenalan Pertama Ruang Lingkup Berlakunya Ilmu Hukum, Buku I, Bandung: Alumni.

Mahmutarom HR., tanpa tahun, Rekontruksi Konsep Keadilan, Semarang: Badan Penerbit Undip.

Rahardjo, Sajipto, 2006, Sisi-Sisi Lain dari Hukum di Indonesia, Jakarta: Penerbit Buku Kompas.

Rasjidi, Lili dan Ira Thania Rasjidi, 2002, Pengantar Filsafat Hukum, Bandung: Mandar Maju.

Sidharta, Bernard Arief, 2010, Ilmu Hukum Indonesia, Bandung: FH Unika Parahyangan.

Sjarif, Amiroedin, 1997, Perundang-undangan Dasar: Jenis dan Teknik Membuatnya, Jakarta: Rineka Cipta.

Soekanto, Soerjono dan Purnadi Purbacaraka, 1993, Perihal Kaidah Hukum, Bandung: Citra Aditya Bakti.

Soeprapto, Maria Farida Indrati, 2010, Ilmu Perundang-Undangan: Jenis, Fungsi, dan Materi Muatan, Yogyakarta: Kanisius.

Vlies, Van de, 1987, Handboek Wetgeving, Zwolle: Tjeenk Willink.

\section{Jurnal:}

Baldwin, Robert \& Martin Cave, 1999, Understanding Regulation: Theory, Strategi and Practice, UK: Oxford University Press, dalam Luky Djani, "Efektivitas-Biaya dalam Pembuatan Legislasi", Jurnal Hukum Jentera, Jakarta, Oktober 2005.

Wibowo, Basuki Rekso, "Peranan Hakim dalam Pembangunan Hukum", artikel dimuat dalam Pro Justitia, Fakultas Hukum Universitas Parahyangan, Tahun XV, Nomor 4, Oktober 1997.

\section{Internet:}

biroorganis asi.jogjaprov.go.id/index. php?option $=$ com_content\&view $=$ article\&id $=2$ 21:pembentukan-peraturan-perundang-undangan 